\title{
Cetacean diversity on the Parnaiba Delta, Maranhão state, northeastern Brazil
}

\author{
Magalhães, FA. ${ }^{\mathrm{a}, \mathrm{b} *}$, Tosi, $C H .{ }^{\mathrm{b}}$, Garri, $R$ G. $^{\mathrm{b}}$, Chellappa, $\mathrm{S}^{\mathrm{a}}$ and Silva, FL. ${ }^{\mathrm{c}}$ \\ aPrograma de Pós-Graduação em Ciências Biológicas, Centro de Biociências, \\ Universidade Federal do Rio Grande do Norte - UFRN, \\ Campus Universitário, Lagoa Nova, 1524, CEP 59072-970, Natal, RN, Brazil \\ 'Projeto Cetáceos do Maranhão, Instituto Ilha do Caju, \\ Av. Presidente Vargas, 235, CEP 64200-200, Parnaíba, PI, Brazil \\ 'Departamento de Ciências Biológicas, Universidade Estadual do Rio Grande do Norte - UERN, \\ Rua Almino Afonso, 478, Centro, CEP 59600-970, Mossoró, RN, Brazil \\ *e-mail: fagneramagalhaes@yahoo.com.br
}

Received January 30, 2007 - Accepted May 30, 2007 - Distributed August 31, 2008

(With 2 Figures)

\begin{abstract}
The increase in the research of cetacean surveys on the Brazilian coast has brought new data on the distribution of species never reported before. The present work reviews the current knowledge on cetaceans species and extends this knowledge with an analysis of cetaceans stranded in the Parnaiba Delta, on the coast of Maranhão State, Brazil. The studies on cetacean diversity on the coast of the Parnaíba Delta were made from August 2004 to August 2006. Fourteen strandings were reported, representing six distinct species, such as the estuarine dolphin (Sotalia guianensis), humpback whale (Megaptera novaeangliae), Bryde's whales (Balaenoptera edeni), dwarf minke whale (Balaenoptera acutorostrata), pigmy killer whale (Feresa attenuata), sperm whale (Physeter macrocephalus) and two specimens which have not yet been identified. The significant degree of cetacean diversity in the region shows that the Parnaíba Delta is, possibly, of an important area for cetacean studies in Brasil.
\end{abstract}

Keywords: cetacean, stranding, Parnaiba Delta, Maranhão, Brazil.

Diversidade de cetáceos no Delta do Parnaíba, estado do Maranhão, nordeste do Brasil

\begin{abstract}
Resumo
Com o aumento das pesquisas voltadas para o monitoramento de cetáceos no litoral brasileiro, registros inéditos sobre a distribuição de espécies têm sido realizados, ampliando o conhecimento sobre áreas de ocorrência dos cetáceos no Brasil. O presente estudo teve por objetivo realizar um levantamento das espécies de cetáceos encalhadas no Delta do Parnaíba, MA. Os estudos foram realizados através de entrevistas com comunidades locais e por meio de coleta direta, entre agosto de 2004 e agosto de 2006. Foram registrados 14 encalhes de cetáceos, com representantes de 6 espécies distintas, até então desconhecidas para a região do Delta do Parnaíba com um exemplar não identificado. Dentre as espécies registradas foram encontrados cinco exemplares do boto-cinza (Sotalia guianensis), um exemplar de baleia-jubarte (Megaptera novaeangliae), três exemplares de baleia-de-bryde (Balaenoptera edeni), um exemplar de baleia-minke-anã (Balaenoptera acutorostrata), um exemplar de orca-pigméia (Feresa attenuata), dois exemplares de cachalote (Physeter macrocephalus) e dois exemplares não identificados que correspondem a um crânio de misticeto e uma escápula de um possível filhote de odontoceto. A significativa diversidade na região do Delta do Parnaíba indica sua relevância para os estudos de cetáceos no Brasil. As análises de idade, baseadas em análises de suturas ósseas dos exemplares encalhados mostram que a região deltaica pode ser utilizada como área de reprodução por algumas espécies como Sotalia guianensis e Balaenoptera edeni.
\end{abstract}

Palavras-Chave: cetáceos, encalhes, Delta do Parnaíba, Maranhão, Brasil. 


\section{Introduction}

The monitoring of beachcast cetaceans can provide information on spatial distribution, seasonal movements and mortality (Woodhouse, 1987). Data collection in prolonged periods and stranding locations can reveal some changes on population relative abundance (Sergeant, 1979). The report of cetacean stranding is, in general, an efficient method to obtain information about these animals. The development and logistical materials to do beach surveys may dispense the utilization of direct catch or capture of live specimens. The obtained data may be partial, but may allow different studies (Raga et al., 1991).

Nowadays, fishermen activities, pollution and ship collisions can be considered the main threats and responsible for a high number of cetacean strandings around the world. As humans increase their exploitation of aquatic resources, individual dolphins, porpoises, and whales suffer, their societies are disrupted and populations decline (Whitehead et al., 2000).

In the beginning of the 1980s, projects for cetacean conservation purposes initiated with the aim of understanding the cause of stranding events. The implementation of these projects were stimulated by the creation of specialized meetings exclusively for aquatic mammals in South America (Simões-Lopes, 2005). Since then, reports about cetaceans on the Brazilian Coast have become more frequent, as well as the collection of carcasses during beach surveys, leading to the understanding of the natural history and distribution of some species along the Brazilian Coast.

In Maranhão, reports on cetacean occurrence were limited to occasional studies. Only one stranding report from an adult Bryde's whale (Balaenoptera edeni Anderson, 1878) specimen was made for the Parnaiba Delta. Another study conducted by Siciliano (1994) analyzed the impact of fishing on coastal populations. The Estuarine Dolphin (Sotalia guianensis van Bénéden, 1864) was considered the most threatened species in Maranhão State (Magalhães et al., 2005).

The absence of projects specialized in studies with cetaceans on the Maranhão coast and more specifically on the Parnaiba Delta is responsible for the lack of information on conservation of coastal communities, which can lead to serious environmental problems, such as bycatch, food source and commercialization of teeth. These problems may encourage the intentional killing of cetaceans and an alternative source for coastal communities must be studied to minimize antropic impacts (Magalhães et al., 2005).

\section{Material and Methods}

The Parnaiba River flows into the Atlantic Ocean via five channels, taking in the Tutoia, Melancieiras, Caju and Canarias bays (IBAMA, 1998). In the coastal zone, the deltaic plain is characterized by sand banks and numerous channels which delimitate the islands, where the salinity varies from 22 ups to 33 ups (Labohidro, 1999). The river presents clayey water due to a great quantity of solid material that comes from erosions occurring on the margins, shaping numerous sand banks.

The Parnaiba Delta $\left(02^{\circ} 45^{\prime} 57.90 " \mathrm{~S}\right.$ and $42^{\circ} 04^{\prime} 52.96^{\prime \prime} \mathrm{W}$ ), is a kind of multiple mouth, ramified in an archipelago composed of seventy islands of varied dimensions, separated by fluvial canals, being the only Delta of the Americas located in the open sea (IBAMA, 1998). The geomorphologic characteristics of the Delta constitute a conspicuous face in the region, with groups of islands, and restingas occupying an area of 2,700 $\mathrm{km}^{2}$ (Labohidro, 1999) (Figure 1).

During the last decades, there has been no attempt to study stranded cetaceans on the Parnaiba Delta. Strandings data for the area have been compiled primarily by people living in the coastal communities that kept the material; only one record has previously been published. In most cases very few details are available for these early records, but verifications of the observations, and some information regarding the condition of the carcass, were obtained with photographs and interviews with fishermen.

The data on the strandings that occurred between 2004 and 2006 were collected by the researchers while working during ten days each month mainly on Caju Island. During this time, the beach was inspected once every month or after information of a stranded animal provided by local fishermen. The efforts were limited by the number of researchers conducting the inspection of $25 \mathrm{~km}$ in length of sandy beach. Survey effort was most comprehensive during the 2005 season. Carcasses of the specimens were classified according to Geraci and Lounsbury (1993) and maturity was estimated according to Jefferson et al. (1993).

\section{Results and Discussion}

Six species of cetaceans were recorded as stranded on the Parnaiba Delta during the last two decades (Figure 2). A greater number of stranding events were recorded from 2004 to 2006 than in other periods (Table 1). The efforts were taken under specific conditions of logistics and transportation, limiting, in many cases, the fieldwork and data collection. We discuss below the species found stranded during the period of study, including direct observations and the events identified by interviews with coastal communities.

\section{Family Balaenopteridae}

\section{Bryde's Whale, Balaenoptera edeni}

Three relatively fresh Bryde's whales were found on the Parnaiba Delta, which washed ashore on the north and east side of Caju Island and on the west of Canarias Island. The first stranding was reported in 1991 by local fishermen and it was the only report published for the region (Almeida, 1994 apud Zerbini et al., 1997). 


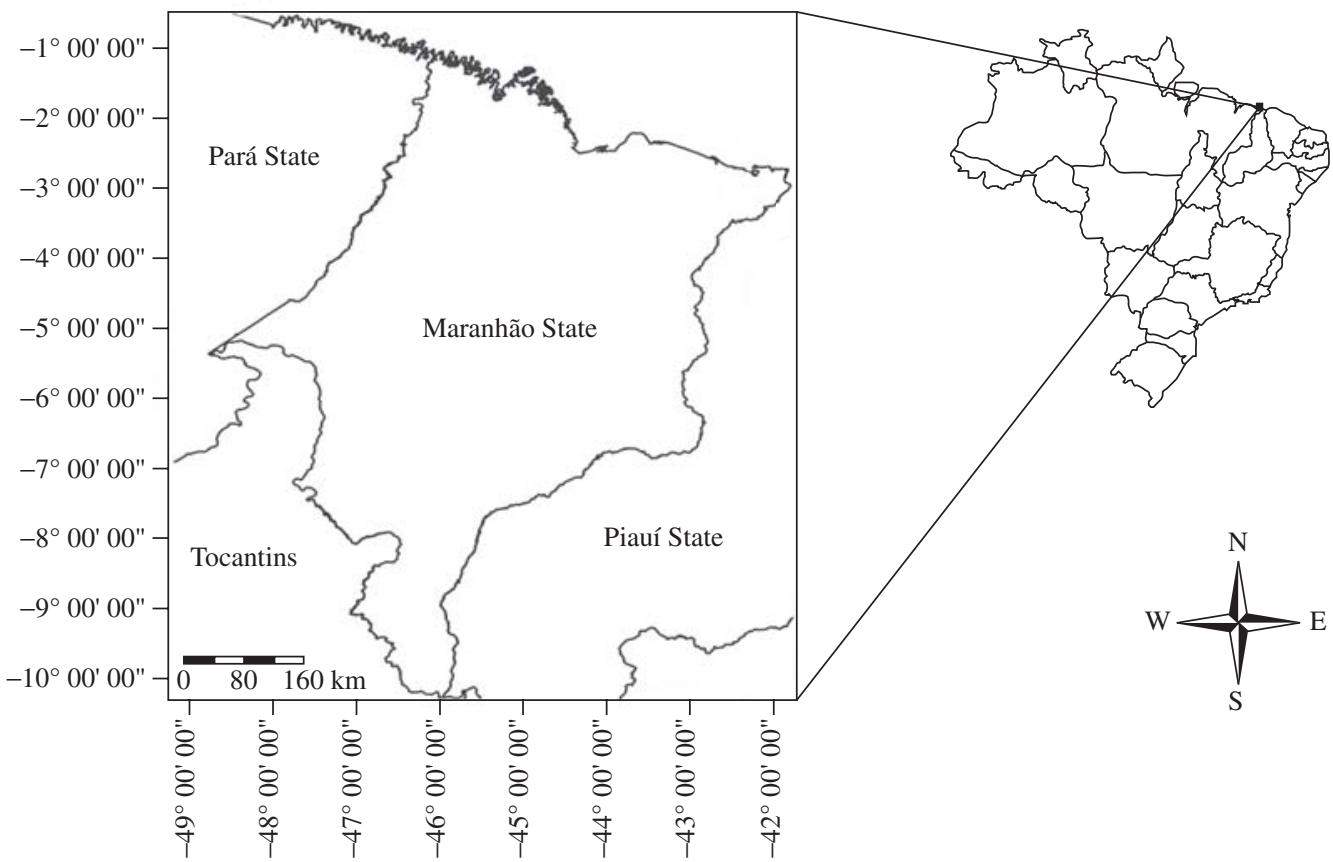

Figure 1. Map of the study area, localized in Parnaiba Delta (black square).

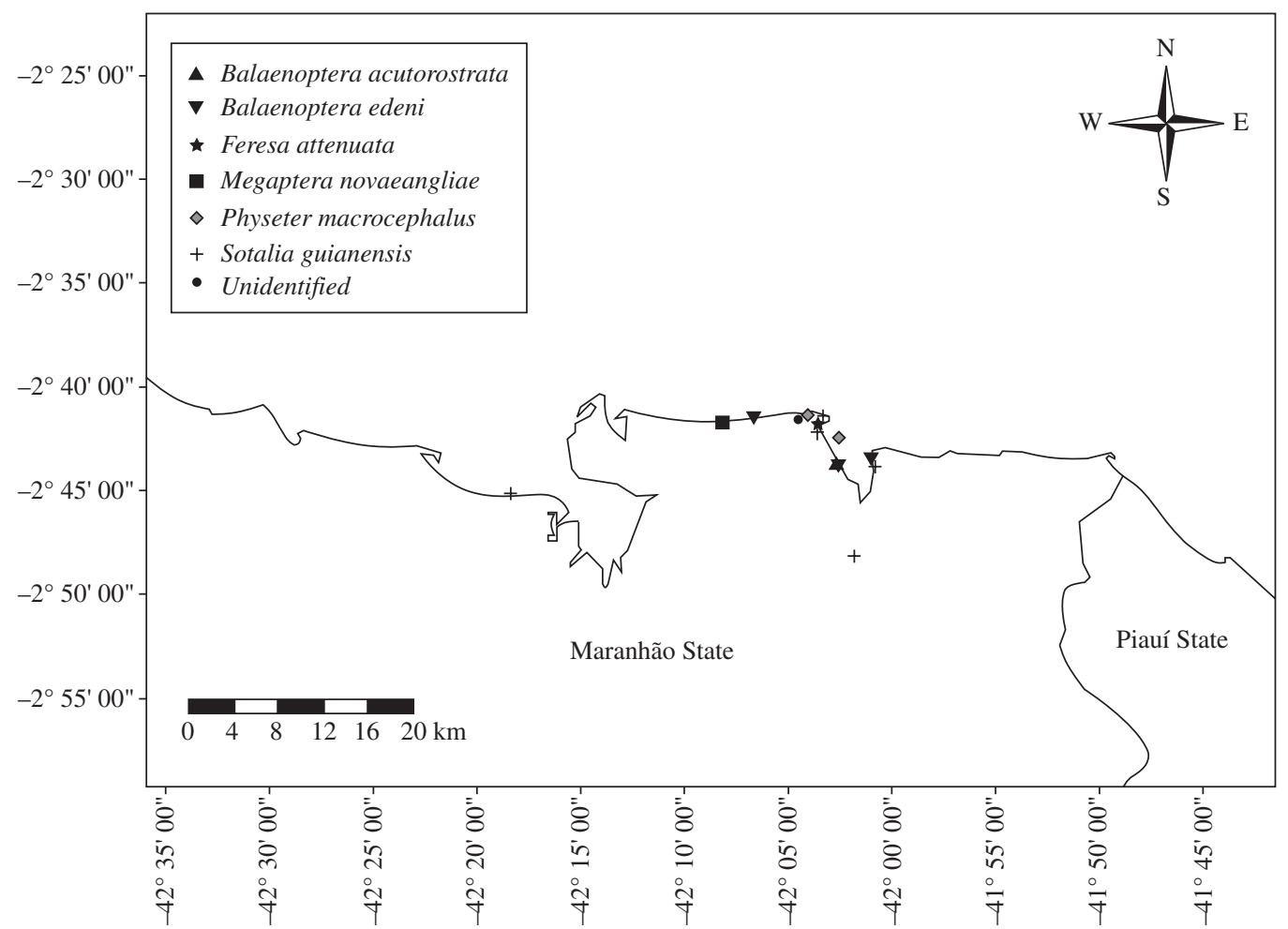

Figure 2. Map of the study area, showing the strandings locations by species

The specimen stranded alive in the Caju Bay, had a total length of 10 to11 m. The carcass could not be examined; however it was used as food by local fishermen. One of the three $B$. edeni strandings was identified as an imma- ture individual and was found in a fresh state in 1999, on the oceanic beach of the Caju Island. The whale was removed by the local community and buried. However the local conditions of wind and the dune movement 
Magalhães, FA. et al.

Table 1. Species stranded on the Parnaiba Delta from August 2005 to August 2006.

\begin{tabular}{|c|c|c|c|c|c|}
\hline Species & $\begin{array}{c}\text { Total length } \\
(\mathbf{m})\end{array}$ & Maturity & Local & Date & Category \\
\hline Megaptera novaeangliae & $14-15^{*}$ & Adult & $\begin{array}{l}\text { Oceanic Beach } \\
\text { (Caju Island) }\end{array}$ & $\begin{array}{l}\text { 80's Decade } \\
\text { (reported on 2005) }\end{array}$ & Dead \\
\hline Balaenoptera edeni & $10^{*}$ & Adult & $\begin{array}{l}\text { Ciumal Beach } \\
\text { (Caju Island) }\end{array}$ & 1991 & Alive \\
\hline Balaenoptera edeni & $10-12 *$ & Adult & Canarias Beach & $\begin{array}{l}1996 \\
\text { (reported on 2005) }\end{array}$ & Alive \\
\hline Balaenoptera edeni & $5 *$ & Neonate & $\begin{array}{l}\text { Oceanic Beach } \\
\text { (Caju Island) }\end{array}$ & $\begin{array}{l}1999 \\
\text { (reported on 2005) }\end{array}$ & Dead \\
\hline Sotalia guianensis & - & Adult & $\begin{array}{l}\text { Mangue Seco Beach } \\
\text { (Caju Island) }\end{array}$ & $\begin{array}{l}2000 \\
\text { (reported on 2005) }\end{array}$ & Dead \\
\hline Balaenoptera acutorostrata & 7.3 & Adult & $\begin{array}{l}\text { Ciumal Beach } \\
\text { (Caju Island) }\end{array}$ & $30 / 07 / 2004$ & Dead \\
\hline Sotalia guianensis & - & Juvenile & $\begin{array}{l}\text { Mangue Seco Beach } \\
\text { (Caju Island) }\end{array}$ & $21 / 01 / 2005$ & Dead \\
\hline Feresa attenuata & - & Juvenile & $\begin{array}{l}\text { Mangue Seco Beach } \\
\text { (Caju Island) }\end{array}$ & $22 / 10 / 2005$ & Dead \\
\hline Physeter macrocephalus & $8.5^{*}$ & - & $\begin{array}{l}\text { Oceanic Beach } \\
\text { (Caju Island) }\end{array}$ & $13 / 04 / 2006$ & Dead \\
\hline Exemplar não identificado & - & Juvenile & $\begin{array}{l}\text { Oceanic Beach } \\
\text { (Caju Island) }\end{array}$ & $\begin{array}{l}\text { 80's Decade } \\
\text { (reported on 2005) }\end{array}$ & Dead \\
\hline Physeter macrocephalus & $8 *$ & Subadult & Passeio Beach & $08 / 2006$ & Dead \\
\hline
\end{tabular}

*Total estimated length.

brought some difficulties to recover the osteological material. It was the first report of a Bryde's whale neonate on the North Brazilian coast, which suggests that the region may be used as a breeding ground. In 1996 another fresh Bryde's whale, approximately $10 \mathrm{~m}$ long and of unknown sex, was found on the west side of Canarias Island. A gunshot mark was noticed, which may have been caused by fishermen in the region. The carcass conditions of the three Bryde's whales stranded on the Parnaiba Delta indicate that they may have died not so far from the study region.

$B$. edeni was reported, in strandings events, on almost all of the Brazilian coast, mainly for the South and Southeast, being one of the most frequent balaenopterid whales on the Brazilian coast, except when compared with minke whales. The present report suggests that Bryde's whales may use the northern Brazilian coast as a breeding, and possibly, feeding ground. Only the Brazilian southeast coast is known for this kind of activity for this species on a nationwide scale.

\section{Dwarf Minke Whale, Balaenoptera acutorostrata}

One already decomposed dwarf minke whale, code 5 according to Geraci and Lounsbury (1993), has been identified at Ciumal Beach, on Caju Island, Parnaiba Delta. It was estimated to be an adult of $7.3 \mathrm{~m}$ in length, stranded on the east side of the island. The skull was removed by the researchers and observations of osteologi- cal material were carried out. An abnormal growth of the occipital bone was recorded; however specific analyses will be carried out to conclude if it represents a pathology.

The dwarf minke whale is commonly found along the eastern coast of South America, from northeastern Brazil $\left(\sim 5^{\circ} \mathrm{S}\right)$ to channels in the Tierra del Fuego in Southern Argentina and Chile $\left(\sim 56^{\circ} \mathrm{S}\right)$ (Baldás and Castello, 1986; Zerbini et al., 1996, 1997). Stranding records suggest a seasonal occurrence of the dwarf minke whale off the coast of Brazil, with peaks in the austral winter and spring (July to September). The occurrence of the species in Northern Brazil has not yet been reported. Williamson (1975) reported that minke whales found on the coast of Brazil, including some dwarf individuals (da Rocha and Braga, 1982), rarely ventured into waters of the northern coast of South America.

The stranding site of this individual is located approximately $500 \mathrm{~km}$ to the north and to the west of the previously known location of records for the species (near Costinha, $\mathrm{PB}, \sim 7^{\circ} \mathrm{S}$ and $35^{\circ} \mathrm{W}$, da Rocha and Braga, 1982). At this point, it is premature to suggest that the dwarf minke whale occurs regularly off the coast of Maranhão. Due to the advanced state of decomposition of the carcass, it is possible that this individual died somewhere within the species' known range and was carried by currents and winds towards the stranding site. It could also represent a strayed animal. Further information needs to be collected to assess whether the occurrence of the dwarf minke whale is regular in this area. 


\section{Humpback Whale, Megaptera novaeangliae}

The only record of a Humpback Whale was from osteological material found by the fishermen community, washed ashore on Oceanica Beach, on the north side of Caju Island in the 1980s. The material was removed by the local community, recovered and deposited in the Caju Island Osteological Collection by the Maranhão State Cetacean Project/Ilha do Caju Institute (PROCEMA/ICEP) in 2004. Unfortunately, the circumstances behind this event could not be investigated.

In Brazil, the calm tropical waters of the Abrolhos Archipelago provides an excellent area for Humpback whale reproduction in the Southern Hemisphere (Rice, 1998), being the only known region for this purpose on the Western South Atlantic.

The present report of this species in the region and the strandings that occurred along Ceara State coast, as documented by Monteiro-Neto et al. (2004), may indicate a possible increase of the humpback whale population along the Southwestern Atlantic, probably extending their distribution area towards the northern coast of Brazil.

\section{Family Physeteridae}

\section{Sperm Whale, Physeter macrocephalus}

Two stranding events with Sperm whales have been reported on the Parnaiba Delta in 2006. One of these, the specimen collected in April 2006 and washed ashore on the north side of the Caju Island, had some parts of osteological material missing; however the lower jaw and teeth were present. This suggests that the whale may have died in an area close to the Parnaiba Delta region. The well decomposed specimen (code 4) was $8.5 \mathrm{~m}$ in total length. Specific observations were made in order to conclude the circumstances of this event.

The specimen found in August 2006 was identified as a sperm whale through an analysis of the skull and was recovered by PROCEMA/ICEP researchers at Passeio Island, on the east side of Caju Island. The carcass of this specimen was not found. There has been no previous record of a stranded sperm whale on the Parnaiba Delta.

According to Ramos et al. (2001), the distribution of sperm whales on the east coast of South America is known from whaling and from strandings that have been regularly reported in the last 40 years (Alves et al. 1996). However, the knowledge about the biology of the species in the South Atlantic is insufficient.

\section{Family Delphinidae}

\section{Pygmy Killer Whale, Feresa attenuata Gray, 1874}

Only one pygmy killer whale had been stranded on the Parnaiba Delta up until 2006. During regular surveys conducted by PROCEMA/ICEP staff, a beach-worn skull of a pygmy killer whale was found, in October 2005, at Mangue Seco beach, on the east side of Caju Island. The degree of fusion of the cranial sutures suggests that this individual was physically immature. The specimen was identified through the following characteristics: short beak, nine to thirteen teeth per row and the distance between the ante-orbital notch and the end of the tooth row (Ross and Leatherwood, 1994). The specimen was deposited in the Caju Island osteological collection.

This stranding suggests that the pygmy killer whale may use oceanic waters close to the Maranhão continental shelf and stranding events along this site may be sporadic. This is the second confirmed stranding of $F$. attenuata for the Brazilian coast and the first one for the northern coast.

The pygmy killer whale is classified as "insufficiently known" by the World Conservation Union-IUCN. In Brazil, only one confirmed record was reported from an emaciated specimen stranded on the southeastern coast (Zerbini and Santos, 1997). Recent interest in cetacean conservation on the northern coast of Brazil has resulted in an increased monitoring effort, which includes field studies and documentation of stranding events (Magalhães et al., 2005).

\section{Estuarine Dolphin, Sotalia guianensis}

This species was the most numerous in stranding events on the Parnaiba Delta. Of the five Estuarine Dolphins found during the period of study with coastal communities, only two were an event stranding and may have died not far from the region. Only the skull was found in both strandings, which has made impossible the identification of sex and the causes of these events. One stranding, in the year 2000, was estimated to be of an adult through the analysis of the sutures of cranial bones, but no other information was collected. In 2005 a skull, but not the carcass, was found on the east beach in Caju Island. The same data was collected as done with the specimen stranded on 2000. However, in this case, the S. guianensis carcass seemed to be of a juvenile animal.

The other three specimens found stranded in 2002, 2005 and 2006 were identified as Sotalia guianensis from photographs and interviews with fishing communities. According to the fishermen the carcasses were found in Carnaubeiras, Tutóia and Canarias Island respectively. The eye, teeth and meat of these specimens were taken to be commercialized and used as shark bait.

S. guianensis is listed as "Insufficiently Known" according to IBAMA (2001) despite its continuous distribution on the east coast of South and Central America (Borobia et al., 1991; da Silva and Best, 1994; Simões-Lopes, 1988). The estuarine dolphin is classified by IBAMA (2001) as highly susceptible, being included in Appendix I and II of CITES (Convention on International Trade in Endangered Species of Wild Flora and Fauna), and in Appendix II of CMS (Convention of 
Migratory Species) and IUCN (The World Conservation Union). Rosas (2006) suggested the classification of the Estuarine Dolphin as 'vulnerable' in the IUCN red list, due to intensive bycatches and marine pollution.

Estuarine Dolphins are commonly found in gillnets along the Brazilian Coast (Siciliano, 1994). Bycatch represents the main threat for this species in Brazil, which can be explained by the preference of coastal and estuarine waters (Di Beneditto et al., 2001). The International Whaling Commission (IWC), in 1994 warned about the procedures that must be taken by researchers and institutions in order to reduce bycatch, and at the same time establish better systems of surveys (IWC, 1995).

\subsection{Unidentified species}

Two specimens stranded in the Parnaiba Delta were not identified due to local tide and the conditions of osteological material collected by the researchers in the local communities. In 2006, a specimen, according to local fishermen, was stranded on the east side of Canarias Island; however, the high tide influenced by meteorological conditions washed the carcass away.

A second specimen was registered in the 1980s in the oceanic beach, localized on the front side of Caju Island. The sutures allowed the conclusion to be drawn that it was a young specimen; however the identification was difficult due to the material decomposition.

\section{Conclusions}

In the last decades and during the past years, the beaches have not been frequently monitored and there have been no personnel available to conduct surveys on the Parnaiba Delta. In 2005 and 2006, there were several research programs throughout the year requiring frequent beach surveys. Comparison of records from 1990 to 2006 showed the increase of stranding events along the years, which could be explained by these regular activities. The cooperation of the fishermen also facilitated the detection of large animal strandings, which remained exposed on the beach for long periods, and so are more noticeable and are thus more likely to be recorded using the fishermen as guides through the waters of the Parnaiba Delta.

The Parnaiba Delta, and more specifically Caju Island, appears to be an excellent location for monitoring cetacean strandings. While the Parnaiba Delta presents over $100 \mathrm{~km}$ of extension in length, Caju Island has only approximately $25 \mathrm{~km}$ of sandy beaches from which $74.5 \%$ of total strandings was reported. Furthermore, the island location allows monitoring of offshore species that might not be found in other locations of Maranhão State. The results support the conclusions that waters around the Parnaiba Delta appear to have a regular diversity of cetacean species. Strandings records on the Delta are especially important to study possible bycatch and also to develop action plans for the conservation of the marine fauna in the region. More studies need to be developed in order to identify if the region presents a significant diversity.

Acknowledgements - We would like to thank PROCEMA/ ICEP for field support; APA of Parnaíba Delta, specially Marcio Barragana and Magnus Severo; CAPES for the financial support during post-graduate studies; Cetacean Society International (CSI) for financial support during field work and Ilha do Caju Institute for the logistical support.

\section{References}

ALVES-JÚNIOR, TT., ÁVILA, FJC., OLIVEIRA, JA., FURTADO-NETO, MA. and MONTEIRO-NETO, C. 1996. Registro de cetáceos para o litoral do Estado do Ceará, Brasil. Arq. Ciên. Mar, Fortaleza, vol. 30, no. 1-2, p. 79-92.

BALDÁS, MI. and CASTELO, HP., 1986. Sobre el hallazgo de ejemplares juveniles de ballena minke, Balaenoptera acutorostrata, en el estuario del rio de la plata y sur de Brasil. In $1^{a}$ Reunião de Trabalho Especialistas em Mamíferos Aquaticos America do Sul. Buenos Aires, Argentina. Abstracts.

BOROBIA, M., SICILIANO, S., LODI, L. and HOEK, W., 1991. Distribuition of the South American dolphin Sotalia fluviatilis. Can. Jour. Zool., vol. 69, p. 1025-1039.

DI-BENEDITTO, APM., RAMOS, RMA. and LIMA, NRW., 2001. Os golfinhos: origem, classificação, captura acidental, hábito alimentar. Porto Alegre: Cinco Continentes. vol. 1, $152 \mathrm{p}$.

GERACI, JR. and LOUNSBURY, V., 1993. Marine Mammals ashore: a field guide for strandings. Texas: Texas A\&M Sea Grant Publications. vol. 1, 305 p.

IBAMA, 1998. Plano de gestão e diagnóstico geoambiental e socioeconômico da APA do Delta do Parnaíba. IBAMA, Ministério do Meio Ambiente, Recursos Hídricos e da Amazônia Legal. Fortaleza: IEPS/UECE. 101 p.

-, 2001. Mamíferos Aquáticos do Brasil: Plano de Ação, Versão II. Brasília: Diretoria de Fauna e Recursos Pesqueiros/IBAMA (Ed.). $96 \mathrm{p}$.

INTERNATIONAL WHALING COMMISSION, 1995. Report of the Scientific Committee. Annex G. Report of the Sub-Committee on Small Cetaceans. Rep. Int. Whal. Commn. vol. 45 , p. $165-179$.

JEFFERSON, TA., LEATHERWOOD, S., and WEBBER, MA., 1993. Marine mammals of the world: FAO Species Identification Guide. Rome: UNEP/FAO. 320 p.

LABOHIDRO, 1999. Diagnóstico ambiental da Ilha do Caju. Relatório síntese das unidades ambientais. Maranhão: Universidade Federal do Maranhão. 94 p.

MAGALHÃES, FA., TOSI, CH. and GARRI, RG., 2005. A recent report on Sotalia fluviatilis (CETACEA: DELPHINIDAE) meat consumption in the east coast of Maranhão, Northeastern Brazil. In 19 Annual meeting of the Society for Conservation Biology. July 15-19 2005. Brasília, Federal District, Brazil. p. 122. Abstract 513 .

MONTEIRO-NETO, C., MEIRELLES, ACO., ALVES, DM., COSTA, AF., BARROS, HR., SILVA, CN., FURTADO NETO, MAA. and LIEN, J., 2004. Cetacean stranding on the coast of the Ceara State, Northeastern Brazil: 1992-2003. In $11^{\circ}$ 
Reunión de Trabajo de Especialistas en Mamíferos Acuáticos de América del Sur. Quito, Ecuador. 171 p.

RAGA, JA., RADUÁN, A., BALBUENA, JA., AGUILAR, A., GRAU, E. and BORELL, A., 1991. Varamientos de cetáceos en las costas españolas del Mediterraneo durante el período 1982 1988. Misc. Zool. vol. 15, p. 215-227.

RAMOS, RMA., SICILIANO, S., BOROBIA, M., ZERBINI, AN., PIZZORNO, JLA., FRAGOSO, ABL., BRITO JR., JL., AZEVEDO, AF., SIMÕES LOPES, PC. and SANTOS, MCO., 2001. A note on strandings and age of sperm whales (Physeter macrocephalus) on the Brazilian coast. Jour. Cetacean Res. Manag. vol. 3, no. 3, p. 321-327.

RICE, DW., 1998, Marine Mammals of the World: Systematics and distribution. Special Publication Number 4. Lawrence, KS, USA: Society for Marine Mammalogy.

ROCHA, JM. and BRAGA, NMA., 1982. Progress report on cetacean research, June 1980 to May 1981. Rep. Int. Whal. Commn., vol. 32, p. 155-159.

ROSAS, FCW., 2006. Natural History of dolphins of the genus Sotalia. In International Workshop on Research and Conservation of the genus Sotalia. Búzios, Rio de Janeiro. $62 \mathrm{p}$.

ROSS, GJB., and LEATHERWOOD, S., 1994. Pygmy Killer Whale, Feresa attenuata (Gray, 1874). In Ridway, SH. and Harrison, SR. (Ed.). Handbook of Marine Mammals. The First Book of Dolphins. vol. 5, p. 387-404.

SERGEANT, DM., 1979. Ecological aspects of cetacean strandings. In Geraci, JB. and St-Aubin, DS. (Ed.). Biology of Marine Mammals: Insights through strandings. Washington, D.C.: Marine Mammal Commission, p. 94-113.

SICILIANO, S., 1994. Review of small cetaceans and fishery interactions in coastal waters of Brazil. Rep. Int. Whal. Commn, Special Issue 15, 241-250 p.
SILVA, VMF. and BEST, RC., 1994. Tucuxi, Sotalia fluviatilis (Gervais, 1853). In Ridgway, SH. and Harrison, R. (Ed.). Handbook of Marine Mammals. London: Academic Press. p. 43-69.

SIMÕES-LOPES, PC., 1988. Ocorrência de uma população de Sotalia fluviatilis Gervais 1853, (Cetácea: Delphinidae) no limite sul de sua distribuição, Santa Catarina, Brasil. Biotemas, vol. 1 , no $1 .$, p. 57-62.

-, 2005. O luar do Delfim: a maravilhosa aventura da história natural. Aldo Brasil (Ed.). Joinville: Letradágua. 304 p.

WHITEHEAD, H., REEVES, RR. and TYACK, PL., 2000. Science and the conservation, protection, and management of wild cetaceans. In Mann, J., Connor, RC., Tyack, PL. and Whitehead, H. (Ed.). Cetacean Societies Field Studies of Dolphins and Whales. Chicago: The University Chicago Press. p. 308-332.

WILLIAMSON, GR., 1975. Minke whales off Brazil. Sci. Rep. Whales Res. Inst.,Tokyo, vol. 27, p. 37-59.

WOODHOUSE, CD., 1987. Marine mammal beachings as indicators of population events. In Reynolds, JE. and Odell, DK. (Ed.). Marine mammal strandings in the United States. Proceedings of the $2^{\text {nd }}$ Marine Mammal Stranding Workshop. Dec 305 1987. Miami, Florida.

ZERBINI, AN., SECCHI, ER., SICILIANO, S. and SIMÕES LOPES, PC., 1996. The dwarf form of the minke whale, Balaenoptera acutorostrata Lacépède 1804, in Brazil. Rep. Int. Whal. Commn. 46. p. 333-40.

-, 1997. Review of the occurrence and distribution of whales of the genus Balaenoptera along the Brazilian coast. Rep. Int. Whal. Commn. vol.47, p. 407-417.

ZERBINI, AN., and SANTOS, MCO., 1997. First record of the pygmy killer whale, Feresa attenuata (Gray, 1874) for the Brazilian coast. Aquatic. Mamm. vol. 23, no. 2, p. 105-109. 